\title{
POTENSI DESA WISATA SEBAGAI ALTERNATIF DESTINASI WISATA NEW NORMAL
}

Syaiful Ade Septemuryantoro

Universitas Dian Nuswantoro, Semarang, Indonesia, email: syaiful.ade@dsn.dinus.ac.id

\begin{abstract}
ABSTRAK
Histori Artikel

Submitted:

2 Juli 2021

Reviewed:

10 Juli 2021

Accepted:

10 Agustus 2021

Published:

15 November 2021

Desa wisata menjadi proyeksi sebagai alternatif destinasi wisata era new normal. Segmen pariwisata berubah seiring dengan era new normal sehingga wisatawan akan memilih destinasi yang bersifat pribadi seperti wisata berbasis alam. Adanya desa wisata yang menerapkan CHSE (Cleanliness, Health, Safety and Environment Sustainability) menyakinkan wisatawan untuk berwisata dengan aman pada desa wisata. Metode penelitian menggunakan analisis kualitatif deskriptif dengan pendekatan studi kasus (case study). Analisis SWOT menunjukkan bahwa potensi desa wisata dapat dikembangkan menjadi desa wisata maju, saat ini terdapat 16 desa wisata yang telah tersertifikasi dan menyusul desa wisata lainnya.
\end{abstract}

Kata Kunci: Potensi, Desa Wisata, New Normal

\section{THE POTENTIAL OF VILLAGE TOURISM AS AN ALTERNATIVE OF NEW NORMAL TOURISM DESTINATIONS}

\begin{abstract}
Tourism villages are projected as an alternative to the new normal era tourist destinations. The tourism segment changes along with the new normal era, so tourists will choose private destinations such as nature based tourism. The existence of a tourist village that implements CHSE (Cleanliness, Health, Safety and Environment Sustainability) assures tourists to travel safely in tourist villages. The research method uses descriptive qualitative analysis with a case study approach. The SWOT analysis shows that the potential of a tourist village can be developed into a developed tourism village, currently there are 16 certified tourist villages and other tourist villages.
\end{abstract}

Keywords: Potential, Tourism Village, New Normal

\section{PENDAHULUAN}

Pertumbuhan industri pariwisata akan berdampak pertumbuhan industri yang lainnya, karena industri pariwisata mempunyai karakter yang bersifat multiplier effect yang sangat besar. Industri pariwisata mempunyai potensi yang besar untuk dikembangkan pada setiap provinsi yang ada di Indonesia, sehingga industri pariwisata mempunyai nilai yang baik serta menjadi produk unggulan pariwisata. Adapun produk unggulan pariwisata antara lain keindahan alam, pertanian, perkebunan, pertambangan, bentang alam, gunung, sungai, dan sebagainya. 
Nilai tambah yang dimaksudkan yaitu agar wisatawan mancanegara maupun wisatawan domestik ketika mengunjungi suatu lokasi wisata dapat menikmati destinasi tersebut secara mudah aman dan tentunya nyaman, sesuai dengan sapta pesona yang menjadi poin kenangan tentunya wisatawan melakukan aktivitas kegiatan wisata dan pulang dapat membawa souvenir atau membeli sesuatu di destinasi yang mereka kunjungi, sehingga wisatawan mendapatkan pengalaman yang mengesankan di destinasi tersebut.

Semua hal tersebut dapat dicapai apabila masyarakat di destinasi mengerti dan memahami pentingnya pariwisata, apabila pariwisata berkembang di daerahnya maka dampak ekonomi yang ditimbulkannya, kesempatan kerja yang ditimbulkannya mampu menjadikan masyarakat ikut andil dalam pengembangan potensi pariwisata di daerahnya masing-masin. (Choiriyah, 2016).

Program yang berorientasi terhadap kemajuan perekonomian terutama sektor pariwisata mengharuskan bahwa perekonomian harus seimbang antara lingkungan perkotaan maupun pedesaan yaitu dengan melakukan program pemberdayaan masyarakat yang nantinya akan menjadi destinasi wisata unggulan. Kemunculan berbagai destinasi wisata baru seiring dengan meredanya pandemi covid-19 memberikan dampak yang baik bagi sektor pariwisata. Destinasi wisata yang berkaitan dengan alam dan kehidupan masyarakat pedesaan menjadi salah satu alternatif yang diharapkan menjadi pilihan penting bagi wisatawan lokal Indonesia. Pandemi covid19 yang mengharuskan para calon wisatawan untuk berdiam diri di rumah merupakan salah satu keputusan yang berat, dimana mereka terbiasa untuk menghabiskan waktu libur terutama hari Minggu untuk berwisata bersama keluarga.

Keputusan yang diambil oleh pemerintah untuk kembali mempercepat industri pariwisata supaya cepat bangkit yaitu dengan memberlakukan protokol kesehatan serta menjaga jarak satu dengan yang lain pada setiap destinasi wisata yang ingin dibuka. Penegakan aturan secara ketat sesuai dengan protokol kesehatan pada setiap destinasi wisata terutama desa wisata. Pentingnya menerapkan protokol kesehatan di desa wisata seiring dengan covid-19 yang menurun yaitu wisatawan lokal akan mencari destinasi yang sekiranya aman dan tidak terlalu jauh dari tempat tinggal.

Seiring dengan pandemi covid-19 yang bukan lagi menjadi ancaman serius oleh para calon wisatawan maka kesiapan suatu destinasi wisata yang tentunya sangat diutamakan. Pembukaan destinasi bukan lagi secara cepat tetapi harus dibuka dengan standar yang ketat untuk menjamin keselamatan para wisatawan. Protokol kesehatan yang meliputi kebersihan, kesehatan, serta keamanan destinasi harus selaras dan perlu untuk dievaluasi setiap saat.

Protokol kesehatan yang nantinya akan diterapkan pada destinasi wisata yang menginginkan untuk membuka kembali kegiatan pariwisata. Tidak hanya kecepatan dalam membuka kembali destinasi wisata akan tetapi perlu dilakukan pembuktian baik data maupun fakta yang ada pada destinasi wisata. Pembuktian data serta fakta adalah dengan data yang menunjukkan berkurangnya angka positif yang terjangkit covid-19.

Masyarakat yang hendak berwisata harus memilih daerah yang termasuk ke dalam zona aman. Zona hijau merupakan zona aman untuk berwisata dan harus sesuai dengan anjuran pemerintah yaitu mematuhi protokol kesehatan berwisata serta menentukan daerah mana yang dipilih yang benar-benar aman. Pemilihan zona hijau menjadikan zona aman untuk berlibur serta menjadi prioritas dalam berwisata karena dapat terhindar dari resiko tertular covid-19. Saat ini Satgas Nasional telah menetapkan 102 daerah yang dikategorikan sebagai zona hijau. (https://covid19.go.id/diakses pada 27 April 2021).

Menurut Septemuryantoro (2017) bahwa pariwisata di Indonesia sangat bergantung terutama pada budaya yang dimiliki oleh 
setiap destinasi wisata terutama budaya pada desa wisata. Indonesia mempunyai keragaman budaya yang beranekaragam sehingga mampu menarik calon wisatawan.

Destinasi wisata yang berkaitan dengan budaya sangat mudah dijumpai pada desa, terutama desa-desa wisata yang berbasis budaya dalam menerima kunjungan tamu. Tentunya calon wisatawan yang akan berkunjung ke desa wisata akan berbeda pada saat pandemi covid-19 ini, calon wisatawan harus mematuhi protokol kesehatan supaya terhindar dari terpapar covid-19.

Pengawasan terhadap destinasi wisata yang akan dibuka tentunya memerlukan kerjasama yang baik serta pengawasan dari dinas yang terkait diantaranya dinas pariwisata dan pemerintah daerah yang nantinya akan berperan secara langsung dalam mengawasi jalannya kegiatan pembukaan destinasi wisata. Desa wisata yang merupakan komunitas masyarakat diantarana terdiri dari masyarakat pada daerah tertentu yang melakukan keterkaitan satu dengan yang lain di bawah pengelolaan serta mempunyai nilai kesadaran dan kepedulian dalam memajukan desa sesuai dengan kemampuan masyarakat dan mampu memberdayakan suatu potensi yang dimiliki oleh desa wisata tersebut sehingga terwujud sapta pesona dalam meningkatkan pembangunan di daerah dengan tujuan memajukan masyarakat serta meningkatkan kesejahteraan (Kemenparekraf RI, 2019).

Destinasi wisata yang terdampak akibat pandemik covid-19 tentunya berdampak terhadap desa wisata. Semenjak bulan Maret 2020, wisatawan tidak lagi melakukan kegiatan wisata dan destinasi wisata mengharuskan untuk tutup demi menjaga keamanan pengunjung tempat wisata tersebut. Tidak ada kegiatan yang bersifat terbuka untuk umum lagi. Kelompok Sadar Wisata (Pokdarwis) beralih fungsi sebagai Satgas Covid 19 yaitu membantu meringankan beban lingkungan dengan berbagi baik dengan tenaga maupun material untuk disumbangkan dan membantu penyaluran bantuan di lingkungannya.
Bulan Juli 2020 ditetapkan sebagai adaptasi kebiasaan baru (new normal) juga masih sangat mengkhawatirkan untuk kembali membuka spot wisata yang ada. Tentunya arahan dari satgas nasional dan pemerintah daerah serta dinas pariwisata yang memberikan pendampingan sebagai edukator, evaluator, komunikator, supervisor, motivator, dan fasilitator dalam membuat kemasan yang aman mendatangkan kembali wisatawan keluarga di tengah pandemik covid-19 dengan adaptasi kebiasaan baru yang pastinya sesuai dengan aturan ketat protokol kesehatan yang harus dipatuhi dan dilaksanakan oleh calon wisatawan.

Adapun permasalahan yang terjadi yaitu desa wisata tidak lagi mempunyai biaya operasional serta kelengkapan dalam membuka kembali destinasi wisata yang tentunya aman untuk calon pengunjung. Adapun peran Kemenparekraf sebagai pemerintah pusat membantu menyediakan bantuan protokol kesehatan sehingga desa wisata terbantu dalam menyediakan sarana protokol kesehatan.

Pembenahan sektor wisata terutama destinasi desa wisata harus benar-benar diperhatikan karena desa wisata diproyeksikan akan menjadi pilihan utama terutama para calon wisatawan lokal yang ingin segera berwisata, tentunya merasa aman pada saat pandemi covid-19 ini. Meredanya wabah virus covid19 menjadikan wisatawan lokal bersiap untuk segera berwisata di desa wisata terutama yang terdekat dengan tempat tinggal.

Desa wisata yang dijadikan salah satu alternatif wisata tentunya harus menerapkan standar protokol kesahatan yang ketat sesuai dengan arahan dari pemerintah diantaranya adalah mencuci tangan sebelum masuk kawasan desa wisata, mengecek suhu tubuh, serta menerapkan jaga jarak antara wisatawan, sehingga calon wisatawan merasa aman 


\section{LITERATUR REVIEW}

Menurut Undang-Undang Republik Indonesia Nomor 90 Tahun 1990 yang memuat arti pariwisata yang dapat diartikan bahwa wisata merupakan jenis perjalanan dimana kegiatan yang dilakukan bersifat sukarela dan bersifat untuk sementara waktu dalam mengunjungi destinasi wisata, serta wisatawan dapat diartikan sebagai orang yang akan melakukan suatu perjalanan ke destinasi wisata.

Pariwisata merupakan hal yang sangat erat kaitannya dengan kegiatan wisata, yang di dalamnya mencakup usaha pada satu objek wisata serta adanya usaha yang ditimbulkan dari dari destinasi wisata tersebut dan kepariwisataan merupakan hal yang erat kaitannya dengan kegiatan penyelenggaraan pariwisata.

Usaha pariwisata merupakan jenis kegiatan yang mempunyai tujuan dalam penyelenggaraan daya tarik wisata serta usaha sarana wisata pada destinasi wisata, serta sasaran wisata menjadi objek dan daya tarik wisata, sedangkan kawasan pariwisata merupakan kawasan dengan areal luasan yang ditujukan untuk memenuhi kebutuhan wisata.

Menurut UNWTO (2019) mengatakan bahwa salah satu kunci penting dalam perekonomian suatu negara adalah sektor pariwisata, dimana sektor ini menjadi salah satu modal dalam meningkatkan kesejahteraan penduduk suatu negara, dengan kata lain sektor pariwisata menjadi sektor ekonomi unggulan dan menjadi sektor yang paling unggul karena mampu tumbuh dengan cepat dan besar di seluruh dunia.

Dukungan masyarakat melalui peran dan kegiatan terutama di industri pariwisata adalah tujuan dari pengembangan sektor pariwisata yang ditemukan oleh United National World Tourism Organization yang terdiri atas keberpihakan pada terciptanya lapangan pekerjaan, pertumbuhan, pengentasan kemiskinan serta keberlangsungan lingkungan.

Sektor pariwisata menjadi sektor terpenting dalam meningkatkan sosial ekonomi masyarakat sehingga peran aktif masyarakat sangat diperlukan. Pariwisata yang menjadikan masyarakat sebagai peran utama dalam kegiatan pariwisata, sehingga sektor pariwisata tersebut bisa tumbuh serta berlanjut dikarenakan pariwisata jenis ini menekankan pada peran aktif masyarakat pada umumnya serta menjadi pengawas pada sektor-sektor pariwisata yang terdapat pada daerah wisata masing-masing. Peran dalam masyarakat yang diharapkan terlibat aktif sebagai kontrol menjadikan daerah pariwisata menjadi teratur dan tentunya berkembang sesuai dengan apa yang mereka butuhkan.

Marinovski (2016) mengemukakan bahwa industri pariwisata memang menjadi salah satu magnet ataupun daya tarik dunia, dan bukanlah menjadi fenomena yang baru tetapi sudah berasal dari masa lampau.

Menurut Spinllane dalam Nugroho (2019), pariwisata telah ditemukan pada awal keberadaan peradaban dunia. Hal ini ditunjukkan bahwa telah terjadi pergerakan manusia dalam melakukan kegiatan keagamaan yaitu perjalanan ziarah yang merupakan salah satu ritual dan tradisi yang dianut oleh umat beragama.

Menurut Pitana dalam Nugroho (2019) bahwa pergeseran perubahaan terhadap peradaban manusia menjadikan pariwisata sebagai salah satu metode perubahan yang di dalamnya mempunyai kekuatan yang luar biasa. Akan tetapi, tidak banyak ditemukan kajian mengenai aspek sosial dan budaya sehingga ilmu kepariwisataan banyak tertinggal dibandingkan dengan rumpun ilmu yang lain.

Menurut Undang-undang No 32 Tahun 2004 yang menyebutkan bahawa desa yaitu sekelompok masyarakat hukum yang memiliki kewenangan dalam mengatur dan mengurus kepentingan masyarakat yang tetap mengedepankan adat istiadat. Menurut Septemuryantoro (2020) bahwa adanya pemberdayaan masyarakat dalam menghadapi tantangan globalisasi sehingga masyarakat harus melestarikan budaya secara berkelanjutan dan turun-temurun.

Menurut Undang-Undang Republik Indonesia nomor 10 Tahun 2009 yang berisi 
tentang kepariwisataan menyebutkan bahwa yang diartikan pariwisata adalah ragam kegiatan yang dilaksanakan serta ditemukan adanya berbagai ragam fasilitas maupun layanan yang telah dipersiapkan oleh masyarakat setempat, pemerintah daerah, stakeholder. Sedangkan menurut Abdurachman dalam Nugroho dkk (2017) menjelaskan bahwa kata pariwisata bersumber dari bahasa sansekerta yang terdiri dari kata pari yang artinya adalah banyak, penuh dan berkeliling-keliling disuatu daerah, sementara kata wisata tersebut artinya perjalanan, sehingga dapat digabungkan bahwa pariwisata merupakan suatu perjalanan yang dilakukan oleh seseorang dari lokasi satu ke lokasi yang lain.

Kepariwisataan adalah sesuatu yang berkaitan erat dengan kegiatan wisata, sedangkan orang yang melakukan wisata dinamakan wisatawan. Lebih jelasnya terdapat beberapa definisi atau pengertian pariwisata yang dikutip dari beberapa ahli salah satunya adalah Mc. Intosh dan Goelder dalam Nugroho (2017) atraksi seni maupun bisnis tentunya dapat menarik serta mendatangkan wisatawan. Pariwisata merupakan rumpun ilmu yang didalamnya terdapat akomodasi serta penyediaan makanan/ katering yang tentunya diminati oleh masyarakat ataupun pengunjung.

Potensi pariwisata yang luar biasa ini menimbulkan suatu dampak perekonomian yang baik sehingga mampu mengangkat taraf hidup penduduk di sekitarnya dengan kata lain potensi pariwisata menjadikan Indonesia sebagai salah satu negara yang wajib dikunjungi.

Seiring dengan bertambahnya kunjungan wisatawan mancanegara ke Indonesia yang menjadikan sektor pariwisata berhasil mengalahkan bidang migas, maka diperlukan strategi maupun arahan yang harus diperhatikan sehingga potensi pariwisata yang ada mampu menjadi keunggulan pada destinasi wisata.

Daerah wisata terutama di Indonesia mempunyai karakteristik yang unik dan beragam terutama budaya, bentang alam, sosiokultural dan lain sebagainya. Sesuai dengan kearifan masyarakat lokal mampu menjadikan pariwisata sebagai sarana dalam meningkatkan taraf hidup masyarakat yaitu dengan tetap bersemboyan pada prinsip gotong-royong dan tetap memperhatikan lingkungan (Arianti, 2014).

Menurut Wiendu dalam Septemuryantoro (2020) bahwa desa wisata adalah wujud keterpaduan antara atraksi, akomodasi dan fasilitas penunjang, dihadirkan dalam sebuah struktur kehidupan masyarakat yang menyatu dengan adat istiadat dan tradisi yang masih dipertahankan sampai sekarang. Ada dua gagasan utama di bidang pariwisata antara lain sarana akomodasi yang ditujukan sebagai tempat hunian bagi penghuni dan / atau hunian yang tumbuh dengan konsep hunian penduduk setempat dan atraksi yang merupakan kehidupan sehari-hari masyarakat serta keadaan normal lingkungan masyarakat yang memungkinkan untuk berinteraksi dengan wisatawan sebagai bagian dari partisipasi aktif yang terdiri atas : pembelajaran budaya tari, kursus bahasa, dan lain sebagainya.

Sedangkan Inskeep (1991) menyebutkan bahwa wisata pedesaan tersebut ditandai dengan adanya sebagian kecil wisatawan yang berada pada lokasi wisata tradisional yang termasuk di dalamnya berinteraksi dengan penduduk dalam mempelajari kehidupan sehari-hari warga dan menemukan potensi wisata yang unik di kawasan tersebut.

Pengembangan desa wisata yang umumnya perlu adanya perencanaan secara matang, sehingga meminimalisir dampak yang diakibatkan dan mudah dalam melakukan pengawasan. Hambatan dan tantangan desa wisata adalah keterbatasan visi maupun kesadaran yang jelas dari masyarakat mengenai arti pentingnya pariwisata, rendahnya minat dan kesadaran masyarakat, berkurangnya kemampuan sumber daya manusia, hambatan budaya dan seringnya tindakan paksaan dan penipuan terhadap wisatawan yang berkunjung.

Untuk mengantisipasi kendala tersebut, pemerintah menentukan kebijakan dengan 
tepat. Adapun peran pemerintah yaitu memberikan kesempatan dan peran sebesarbesarnya kepada masyarakat dalam pengembangan pariwisata, memberdayakan masyarakat dengan mengalokasikan dana, memperkuat kelembagaan dan meningkatkan kapasitas dan kemandirian serta berkontribusi pada pembangunan sebesar-besarnya.

Hal ini memberikan kebebasan keinginan kelompok masyarakat dimana mampu mengembangkan potensi Desa wisata dapat menghasilkan produk pariwisata lokal sebagai dasar perencanaan dan pemasaran produk dalam mendukung dan meningkatkan perekonomian masyarakat. Septemuryantoro (2020) bahwa desa wisata merupakan bentuk suatu komunitas masyarakat yang di dalamnya terdiri atas penduduk yang mendiami lokasi serta adanya interaksi yang dilakukan secara langsung dengan pengelolaan desa serta mempunyai tingkat kesadaran dan kepedulian terhadap potensi yang ada di dalamnya.

\section{METODE}

Penulis menggunakan metode yang bersifat metode penelitian deskriptif kualitatif, penelitian kualitatif deskriptif adalah berupa penelitian dengan metode atau pendekatan studi kasus (case study) menurut Rukin dalam Nugroho (2017) penelitian kualitatif adalah riset yang bersifat deskriptif dan cenderung meggunakan analisis dengan pendekatan induktif.

Penonjolan proses penelitian dan pemanfaatan landasan teori dilakukan agar fokus penelitian sesuai dengan fakta di lapangan. Penelitian menurut Soekanto dalam Nugroho (2019) bahwa penelitian merupakan suatu kegiatan ilmiah yang didasarkan pada analisis dan konstruksi yang dilakukan secara sistematis, untuk mengungkapkan kebenaran sebagai salah satu manifestasi keinginan manusia untuk mengetahui apa yang sedang di hadapinya.

Menurut Sugiono (2017) penelitian kualitatif adalah jenis penelitian yang temuantemuannya tidak diperoleh melalui prosedur statistik atau bentuk hitungan lainnya dan bertujuan mengungkapkan gejala secara holistik-kontekstual melalui pengumpulan data dari latar alami dengan memanfaatkan diri penulis sebagai instrumen kunci. Penelitian kualitatif bersifat deksriptif dan cenderung menggunakan analisis pendekatan induktif.

Sedangkan menurut Cresswell (2015) penelitian kualitatif dimulai dengan asumsi dan penggunaan kerangka penafsiran / teoritis yang membentuk atau mempengaruhi studi tentang permasalahan riset yang terkait dengan makna yang dikenakan oleh individu atau kelompok pada suatu permasalahan sosial atau manusia.

Mempelajari permasalahan menggunakan pendekatan kualitatif mutakhir dalam penelitian pengumpulan data, dalam lingkungan alamiah, yang peka terhadap masyarakat, tempat penilitian. Analisis data yang bersifat induktif maupun deduktif, pembentukan pola atau tema laporan atau presentasi tertulis akhir mencakup berbagai suara dari para partisipan, refleksivitas dari peneliti, deskripsi dan interpretasi tentang masalah penelitian, kontribusinya pada literatur atau seruan bagi perubahan.

Menurut Denzin dan Lincoln dalam Nugroho (2020) bahwa penelitian kualitatif adalah penelitian yang menggunakan latar belakar alamiah dengan maksud menafsirkan fenomena yang terjadi dan dilakukan dengan jalan melibatkan berbagau metode yang ada.

\section{HASIL DAN PEMBAHASAN}

Desa wisata merupakan salah satu aspek yang mampu menjawab tren pariwisata di era new normal (era setelah pandemi covid19), desa wisata lebih dikonsentrasikan dengan tujuan quality tourism dengan menghadirkan aktivitas yang berkaitan dengan alam sekitar. Pandemi Covid-19 sangat berdampak bagi industri pariwisata di Indonesia. Wisatawan akan berengaruh besar pada pariwisata di 
tanah air. Pasca pandemi nanti wisatawan yang berkunjung ke suatu destinasi jumlahnya akan lebih sedikit. Karena itu, ke depan tren pariwisata Indonesia akan mengedepankan beberapa konsep pariwisata yang personalized dan customized.

Seiring dengan pernyataan Menteri Pariwisata dan Ekonomi Kreatif (Menparekraf) yang mengatakan bahwa adanya fenomena pariwisata pasca pandemi sehingga harus melihat potensi untuk mengembangkan daya tarik desa wisata dengan berpedoman pada pariwisata yang berkelanjutan.

Seiring dengan Wijayanti dkk (2017) bahwa dengan desa wisata mampu mengembangkan pariwisata dengan mengedepankan kontribusi pada pelestarian lingkungan yang ada di pedesaan. Desa wisata harus mempunyai karakteristik yang kuat dalam hal ini desa wisata harus mempunyai nilai budaya yang dijaga keasliannya. Adapun desa wisata harus memenuhi beberapa persyaratan antara lain mempunyai akses yang baik sehingga memudahkan calon wisatawan untuk menjangkau lokasi baik dengan berbagai macam transportasi, mempunyai objek wisata yang menarik untuk dikunjungi, mempunyai kekayaan alam, seni budaya, makanan tradisional, legenda yang menarik bagi calon wisatawan, mempunyai dukungan dari masyarakat setempat serta aparatur desa, mempunyai jaminan keamanan bagi calon wisatawan, mempunyai sarana telekomunikasi yang baik, mempunyai iklim yang dingin dan segar, mempunyai hubungan yang baik antara objek wisata terdekat.

Desa wisata mempunyai proyeksi akan menjadi tren wisata pada era new normal. Pariwisata yang mengalami perubahan tren karena adanya pandemi covid19 sehingga mengharuskan wisatawan memilih destinasi wisata yang aman dan nyaman bagi wisatawan.

Desa wisata menjadi proyeksi untuk keberlanjutan lingkungan yang berkarakter kearifan lokal serta mengedepankan budaya. Segmen pariwisata berubah seiring dengan era new normal sehingga wisatawan akan memilih destinasi yang bersifat pribadi seperti wisata berbasis alam.

Pengembangan desa wisata dengan berbasis CHSE (Cleanliness, Health, Safety and Environment Sustainability) semakin menyakinkan calon wisatawan untuk berwisata dengan aman pada destinasi wisata yang mereka pilih. Era pandemi ini menjadikan situasi yang lebih baik lagi ke depan sehingga perlu untuk memperhatikan upaya untuk konsolidasi dalam rangka meningkatkan kualitas pariwisata yang ada di Indonesia sehingga poin utama dari suatu destinasi, dalam hal ini adalah desa wisata yang menjadi salah satu destinasi unggulan pada era new normal.

Sebuah destinasi yang lebih besar dari produk wisata itu sebenarnya merupakan salah satu bentuk pengalaman yang dicari oleh pasar. Pariwisata dalam waktu dekat ini akan menjadi sebuah momentum yang baik bagi desa wisata, dimana situasi ke depannya akan menjadi lebih baik seiring dengan kunjungan wisatawan. Perjalanan wisatawan ke suatu destinasi wisata akhir-akhir ini perlu diperhatikan dalam rangka meningkatkan kualitas pariwisata yang jelas merupakan poin utama dari sebuah destinasi apakah destinasi wisata tersebut memberikan pengalaman yang dicari oleh pasar atau perilaku pasar masa kini. Pengalaman holistik yang mampu mengkombinasikan tidak hanya pengalaman untuk wisatawan tetapi kepuasan wisatawan. Kombinasi pariwisata demi mendapatkan pengalaman dan kepuasan juga.

Indonesia mempunyai 16 Desa wisata yang telah mendapatkan sertifikasi antara lain desa wisata Batulayang di Kabupaten Bogor, desa wisata Kandri di Kota Semarang, desa wisata Lerep di Kabupaten Semaran, desa wisata Candirejo di Kabupaten Magelang, desa wisata Nglanggeran di Kabupaten Gunung Kidul, desa wisata Petingsari di Kabupaten Sleman, desa wisata Karangrejo di Kabupaten Magelang. https://kemenparekraf.go.id/diakses pada 25 April 2021

Menurut Kotler dan Keller (2016) bahwa 
evaluasi secara keseluruhan mempunyai kekuatan, kelemahan, peluang serta ancaman. Analisis SWOT digunakan dalam pengembangan desa wisata yang mampu menjadi destinasi wisata alternatif new normal.

Tabel 1. Matriks SWOT Potensi Desa Wisata

\begin{tabular}{|c|c|c|}
\hline Matrik SWOT & $\begin{array}{l}\text { Peluang-Opportunity }(\mathbf{O}) \\
\text { 1. Adanya support dari } \\
\text { kemenparekraf } \\
\text { 2. Topografi desa yang masih } \\
\text { terjaga }\end{array}$ & $\begin{array}{l}\text { Ancaman-Threat }(\mathbf{T}) \\
\text { 1. Lokasi yang kurang strategi } \\
\text { 2. Transportasi dan } \\
\text { telekomunikasi kurang }\end{array}$ \\
\hline $\begin{array}{l}\text { Kekuatan-Strength } \\
\text { (S) }\end{array}$ & $\begin{array}{l}\text { (S1,2-O1,2) potensi desa wisata } \\
\text { yang dapat dipromosikan kepada }\end{array}$ & $\begin{array}{l}(\mathrm{S} 1,2-\mathrm{T} 1,2) \text { meningkatkan } \\
\text { sarana dan prasarana pendukung }\end{array}$ \\
\hline $\begin{array}{l}\text { 1. Mempunyai kekayaan alam yang } \\
\text { masih asli } \\
\text { 2. Mempunyai keunggulan adat istiadat } \\
\text { dan budaya daerah }\end{array}$ & khalayak umum & \\
\hline Kelemahan-Weakness (W) & 1. (W1-O1,2) meningkatkan & 1. (W1,2-T1,2) melakukan \\
\hline 1. Wawasan potensi desa masih kurang & kerjasama pihak luar & promosi secara efektif \\
\hline $\begin{array}{l}\text { 2. Keterampilan dalam pengelolaan } \\
\text { produk }\end{array}$ & $\begin{array}{l}\text { 2. (W2-O1,2) mengadakan } \\
\text { pengolahan produk }\end{array}$ & $\begin{array}{l}\text { 2. }(\mathrm{W} 3-\mathrm{T}) \text { pendampingan dan } \\
\text { pelatihan terhadap masyakarat }\end{array}$ \\
\hline 3. Motivasi yang kurang & $\begin{array}{l}\text { 3. (W3-O1) mngadakan } \\
\text { pelatihan dan pendampingan }\end{array}$ & desa wisata \\
\hline
\end{tabular}

Berdasarkan matriks SWOT di atas menunjukkan bahwa desa wisata yang pada mulanya hanya sebagai desa biasa dengan kearifan lokal, kemudian potensi yang ada di desa tersebut dapat dikembangkan dengan tetap melestarikan kebudayaan lokal yang tetap dijunjung tinggi. Adanya atraksi yang menjadi daya tarik wisata harus dikembangkan dengan membuat paket wisata yang ditujukan untuk calon wisatawan. Adapun manfaat pembangunan desa wisata antara lain dapat meningkatkan perekonomian bagi masyarakat desa, mampu menyediakan lapangan pekerjaan bagi masyarakat desa sehingga mampu memutar roda perekonomian yang ada di desa tersebut, mampu meningkatkan kualitas sumberdaya manusia dengan menerapkan pelatihan dan pendampingan, mampu mengenalkan kearifan budaya dan adat istiadat kepada wisatawan tanpa mengubah kebudayaan tersebut serta mampu meningkatkan kualitas sarana dan prasarana desa sehingga mendukung pariwisata di desa tersebut

Pengalaman dan kepuasan yang diharapkan oleh wisatawan cukup tinggi, termasuk lingkungan, jadi jelas yang kita butuhkan adalah bagaimana membangun keseimbangan konvergensi agar kita tidak hanya membangun pariwisata tetapi bagaimana pariwisata dapat berkembang. Lingkungan desa wisata, bagaimana lingkungan pedesaan dapat menciptakan rasa ingin selalu kembali ke tempat tersebut. Terciptanya perasaan yang selalu ingin kembali mampu menjadikan sebuah wisata mampu meningkatkan dan menciptakan kepuasan bagi wisatawan. Kearifan lokal pada desa wisata harus ditampilkan dalam kehidupan sehari-hari dan tradisi adat istiadat dan budaya harus tetap dijaga kelestariannya. Pengalaman dan kepuasan yang tinggi termasuk lingkungan desa, jadi jelas bahwa yang dibutuhkan untuk membangun desa wisata perlu adanya keseimbangan konvergensi sehingga dapat membantu keberlangsungan desa wisata. Desa wisata harus bangkit untuk menjadi salah satu alternatif wisata di era new normal. Peningkatan kualitas desa wisata tentunya tidak lepas dari pendampingan terhadap desa wisata. Adanya pendampingan secara terusmenerus kepada desa wisata diharapkan desa wisata menjadi lebih siap lagi dalam menyongsong wisatawan di era new normal. Perguruan tinggi sebagai mitra desa wisata menjadikan salah satu aspek yang memungkinkan percepatan desa wisata dalam menyongsong tamu. Sesuai dengan arahan dari Kemenparekraf 2021 bahwa 
terdapat target desa wisata 2021-2024 adalah 244 desa wisata, dengan rincian pada tahun 2021 terdapat 67 desa wisata, tahun 2022 terdapat 63 desa wisata, tahun 2023 terdapat 59 da tahun 2024 sebanyak 55 desa wisata. Adapun klasifikasi desa wisata terdapat 4 klasifikasi antara lain desa wisata rintisan yang mempunyai potensi tetapi masih minim sarana dan prasarananya, belum atau sedikit kunjungan wisatawan, kesadaran masyarakat masih belum tumbuh terhadap potensi yang ada di desa, sangat diperlukan pendampingan dari pihak terkait. Desa wisata berkembang umumnya sudah ada kunjungan wisatawan yang berasal dari luar daerah tersebut, sarana dan prasarana yang ada di desa wisata sudah berkembang, mulai terciptanya lapangan pekerjaan bagi masyarakat desa, adanya kesadaran masyarakat terhadap potensi wisata yang ada serta masih perlunya pendampingan dari pihak-pihak yang terkait. Desa wisata wisata yang termasuk kategori maju yaitu masyarakat sudah sadar akan wisata sehingga adanya kunjungan wisatawan domestik maupun wisatawan mancanegara serta masyarakat mampu mengelola usaha yang dijalankan terutama pariwisata dengan melalui kelompok sadar wisata (Pokdarwis). Desa wisata maju mampu memanfaatkan dana desa yang diberikan oleh pemerintah yang ditujukan untuk pengembangan desa wisata, dan desa mandiri yang merupakan desa wisata yang telah mempunyai beragam inovasi yang dikembangkan oleh masyarakat menjadi suatu unit kewirausahaan yang mandiri dan dikelola oleh masyarakat desa wisata tersebut. Desa wisata maju telah dikenal oleh mancanegara karena menerapkan sebuah konsep yang berlanjut sehingga diakui oleh dunia, selain itu sarana dan prasarana yang ada telah memenuhi standar yang telah ditetapkan oleh internasional minimal di tingkat ASEAN. Adanya pengelolaan yang bersifat pentahelix sehingga bersifat kolaboratif, adanya dana desa oleh pemerintah merupakan salah satu inovasi produk wisata yang ada dengan memanfaatkan digitalisasi sebagai bentuk promosi mandiri.
Tujuan pengembangan desa wisata sebagai alternatif wisata di era new normal selaras dengan Undang-undang no 10 tahun 2009 tentang kepariwisataan yaitu dapat meningkatkan pertumbuhan ekonomi masyarakat, meningkatkan kesejahteraan masyarakat, adanya upaya untuk menghapus angka kemiskinan, mengatasi masalah pengangguran, dapat melestarikan alam serta lingkungan dan sumber daya yang mampu memajukan kebudayaan sekitar.

Desa wisata dipilih sebagai alternatif wisata dengan tetap menonjolkan wisata budaya yang berbasis pelestarian dan pengalaman sumberdaya yang ada. Wisata yang sehat sesuai dengan Keputusan Menteri Kesehatan Republik Indonesia Nomor HK.01.07/ MENKES/382/2020 tentang protokol kesehatan bagi masyarakat di tempat dan fasilitas umum dalam rangka pencegahan dan pengendalian corona virus disease 2019 (Covid-19). Wisata sehat perlu ditekankan CHSE (Cleanliness, Health, Safety and Environment Sustainability) yang harus dipenuhi sebagai syarat untuk menerima wisatawan terutama pada desa wisata. Desa wisata yang telah menerapkan CHSE dan memenuhi persyaratan tersebut menjadi sebuah peluang untuk menyambut tamu wisatawan.

Ada beberapa penentuan desa wisata diantaranya terdapat sumberdaya manusia serta masyarakat di desa wisat yang mempunyai peran sebagai penggerak motor wisata di desa, desa wisata tersebut sudah mempunyai surat keputusan Bupati setempat. Pemerintah daerah telah mempunyai RIPPARDA dan mempunyai target yang akan dicapai dalam pariwisata, selain itu adanya pengeluaran biaya yang berasal dari desa wisata. Peran Kemenparekraf sebagai salah satu pendorong percepatan desa wisata mempunyai salah satu peran yaitu membuat profil desa wisata, kemudian ikut membantu membuat perencanaan pembangunan desa wisata yang berkelanjutan baik pembangunan sumberdaya manusia, pembangunan sarana dan prasarana pendukung serta adanya pembangunan fisik 
yang berkaitan dengan prasarana pendukung wisata di desa tersebut.

Sebenarnya pengalaman dan kepuasan tamu dalam menilai suatu desa wisata adalah dengan sense of place dimana membuat suatu rasa akan kembali lagi ke desa wisata tersebut. Nilai kearifan budaya yang ditonjolkan pada desa wisata sebenarnya mampu menjadi magnet daya tarik wisata. Kearifan lokal harus didemonstrasikan dalam kehidupan sehari-hari seperti misalnya tradisi budaya, adat istiadat, kebiasaan makan dan minum serta nilai-nilai budaya yang terkandung di dalamnya. Wisatawan yang berkunjung ke desa wisata biasanya mencari suasana yang baru dengan keindahan alamnya, desa wisata tidak terlalu tergesa-gesa dalam melakukan pembangunan, artinya bahwa jangan sekalikali membangun dengan ukuran-ukuran wisatawan akan tetapu membangun tanpa merusak kelestarian alam yang asli, sehingga wisatawan akan menikmati keindahan alam serta ragam budaya yang ada di desa wisata tersebut. Beberapa desa wisata juga akan mengadaptasi teknologi dalam upaya percepatan desa wisata sehingga teknologi yang digunakan tidak serta merta menggantikan kearifan lokal akan tetapi dengan adanya teknologi memungkinkan desa wisata akan jauh lebih dikenal oleh calon wisatawan. salah satu contoh pemanfaatan teknologi adalah virtual tour.

Pandemi Covid-19 yang hampir satu tahun melanda dunia, dimana virus ini merupakan wabah global yang berdampak buruk pada dimensi manusia dan sosial. Setelah menyebar dari Cina, pandemi meluas dengan cepat ke 210 negara termasuk Indonesia. Pandemi Covid-19 adalah kejutan besar bagi ekonomi global termasuk Indonesia. Ekonomi mengalami penurunan setidaknya untuk paruh pertama tahun ini dan mungkin lebih lama jika tindakan penahanan wabah Covid-19 tidak efektif. Pandemi Covid-19 menyebabkan gangguan pada rantai pasok global, dalam negeri, volatilitas pasar keuangan, guncangan permintaan konsumen dan dampak negatif di sektorsektor utama seperti perjalanan dan pariwisata.
Dampak wabah Covid-19 tidak diragukan lagi akan terasa di seluruh rantai nilai pariwisata. Perusahaan kecil dan menengah diperkirakan akan sangat terpengaruh. Tekanan pada industri pariwisata sangat terlihat pada penurunan yang besar dari kedatangan wisatawan mancanegara dengan pembatalan besar-besaran dan penurunan pemesanan. Penurunan juga terjadi karena perlambatan perjalanan domestik, terutama karena keengganan masyarakat Indonesia untuk melakukan perjalanan, khawatir dengan dampak Covid-19.

Penurunan bisnis pariwisata dan perjalanan berdampak pada usaha UMKM, dan terganggunya lapangan kerja. Padahal selama ini pariwisata merupakan sektor padat karya yang menyerap lebih dari 13 juta pekerja. Angka itu belum termasuk dampak turunan atau multiplier effect yang mengikuti termasuk industri turunan yang terbentuk di bawahnya (Bappenas, 2020).

Indonesia sendiri, Menteri Pariwisata dan Ekonomi Kreatif mengatakan ada lebih dari 13 juta pekerja sektor pariwisata dan 32,5 juta pekerja yang secara tidak langsung terkait pariwisata, yang berisiko terimbas pandemi. Ini terjadi karena hampir seluruh destinasi wisata ditutup guna mencegah penyebaran virus.

Selain itu, ribuan hotel, ratusan restoran dan agen travel juga sudah tutup. Industri penerbangan pun tak luput dari imbasnya, dimana ratusan pesawat akhirnya menganggur karena adanya batasan dalam mobilitas masyarakat. Teknologi yang mampu menjembatani dalam meningkatkan upaya untuk kemajuan desa wisata dengan memanfaatkan virtual tour dan story telling desa wisata. Wisatawan akan mempunyai banyak pilihan dalam menentukan apakah nantinya akan berkunjung secara langsung dengan menerapkan protokol kesehatan atau dengan virtual tour.

Penerapan CHSE di desa wisata harus benarbenar dilaksanakan supaya nantinya memberikan rasa aman terhadap wisatawan serta akan menimbulkan rasa ingin kembali mengunjungi desa wisata dengan mengajak sanak saudara. 
Pelestarian sumberdaya yang ada di desa wisata juga perlu diperhatikan terutama bagi masyarakat untuk lebih menjaga kelestarian lingkungan hidup yang merupakan tantangan ke depannya sehingga keberadaan desa wisata dengan kebudayaan asli serta adanya kelestarian lingkungan dengan tetap terjaga dan tidak lupa turut menerapkan CHSE (Cleanliness, Health, Safety and Environment Sustainability). Bahwa dengan kekuatan desa wisata maka dipastikan pariwisata di Indonesia tetap memberikan kontribusi yang positif bagi pendapatan negara diluar sektor migas, sehingga masyarakat akan tetap memilih untuk bewisata secara aman dan nyaman salah satunya dengan memilih desa wisata sebagai alternatif destinasi wisata di era new normal dengan demikian perekonomian akan terus berputar.

\section{SIMPULAN}

Desa wisata menjadi proyeksi untuk keberlanjutan lingkungan yang berkarakter kearifan lokal serta mengedepankan budaya. Segmen pariwisata berubah seiring dengan era new normal sehingga wisatawan akan memilih destinasi yang bersifat pribadi seperti wisata berbasis alam. Adanya desa wisata yang menerapkan CHSE (Cleanliness, Health, Safety and Environment Sustainability) semakin menyakinkan calon wisatawan untuk berwisata dengan aman pada destinasi wisata yang mereka pilih. Analisis SWOT menunjukkan bahwa potensi desa wisata masih sangat terbuka untuk dikembangkan menjadi desa wisata maju, saat ini terdapat 16 desa wisata yang telah tersertifikasi dan menyusul desa wisata lainnya. Era pandemi ini menjadikan situasi yang lebih baik lagi ke depan sehingga perlu untuk memperhatikan upaya untuk konsolidasi dalam rangka meningkatkan kualitas pariwisata yang ada di Indonesia sehingga poin utama dari suatu destinasi, dalam hal ini adalah desa wisata yang menjadi salah satu destinasi unggulan pada era new normal.
Pelestarian sumberdaya yang ada di desa wisata juga perlu diperhatikan terutama bagi masyarakat untuk lebih menjaga kelestarian lingkungan hidup yang merupakan tantangan ke depannya, dan kita harus bangga bahwa dengan kekuatan desa wisata maka dipastikan pariwisata di Indonesia tetap memberikan kontribusi yang positif bagi pendapatan negara diluar sektor migas, sehingga masyarakat akan tetap memilih untuk bewisata secara aman dan nyaman salah satunya dengan memilih desa wisata sebagai alternatif destinasi wisata di era new normal.

\section{REFERENSI}

Anonim. Undang Undang tentang Kepariwisataan, UU No. 10 Tahun 2009. Jakarta: Direktorat Jenderal Hukum dan HAM

Anonim. Undang Undang tentang Kepariwisataan, UU No. 9 Tahun 1990. Jakarta: Menteri Sekretaris Negara

Arianti, D. (2014). Pengaruh Sektor Pariwisata Terhadap Perekonomian dan Keruangan Kota Bukittinggi (Pendekatan Analisis Input Output). Jurnal Wilayah dan Lingkungan, 2(3), 183-196.

Choiriyah, I. U. (2016). Pemberdayaan Masyarakat melalui Program Sutera Emas (Studi pada Inovasi Pelayanan Kesehatan di Puskesmas Kepanjen, Kabupaten Malang). JKMP (Jurnal Kebijakan dan Manajemen Publik), 4(1), 57-74.

Creswell, J. (2015). Educational Research: Planning, Conducting, and Evaluating Quantitative and Qualitative Research. New York: Pearson.

https://kemenparekraf.go.id/diakses pada 25 April 2021

https://covid19.go.id/diakses pada 27 April 2021 
Inskeep, E. (1991). Tourism planning: An integrated and sustainable development approach. John Wiley \& Sons.

Kementerian Pariwisata. (2019). Buku Panduan Program Pengembangan Desa Wisata Berbasis Pendampingan melalui PT. Asdep Pengembangan SDM Pariwisata.

Keputusan Menteri Kesehatan Republik Indonesia Nomor HK.01.07/ MENKES/382/2020 tentang protokol kesehatan bagi masyarakat di tempat dan fasilitas umum dalam rangka pencegahan dan pengendalian corona virus disease 2019 (Covid-19)

Kotler, Philip and Kevin Lane Keller, 2016. Marketing Management, 15th Edition, Pearson Education,Inc.

Marinovski, Caroline. (2016). Community development approach to communitybased

Nugroho, R. A., Septemuryantoro, S. A., \& Lewa, A. H. (2017). Penerjemahan: sebuah cara untuk meningkatkan kualitas pariwisata Indonesia.

Nugroho, R. A. (2019). Sustaining tourists' revisit intention through talk-ininteraction model: a multicultural communication analysis of guest and homestay host. In Conservation and Promotion of Heritage Tourism (pp. 134). IGI Global.

Septemuryantoro, S. A. (2017). Potensi

Wisata Budaya Jalur Gula dalam

Menunjang Kenaikan Kunjungan Tamu

Hotel di Kota Semarang. LITE: Jurnal

Bahasa, Sastra, dan Budaya, 13(2), 174-194.

Septemuryantoro, S. A. (2020).

Pengembangan Potensi Budaya

Ekowisata melalui Pemberdayaan
Masyarakat Desa Wisata Candirejo

Borobudur Jawa Tengah. Media

Wisata, 18(2), 210-222.

Sugiyono. (2017). Metode Penelitian

Kuantitatif, Kualitatif, dan $R \& D$.

Bandung : Alfabeta, CV.

Undang-undang No. 32 Tahun 2004 tentang Pemerintah Daerah.

Wijayanti, A., Damanik, J., \& Fandeli, C. (2017). Analysis of supply and demand to enhance educational tourism experience in the smart park of Yogyakarta, Indonesia. Economies, 5(4), 42.

World Tourism Organization, U. (2019). Why tourism? Retrieved April 27, 2021, from World Tourism Organization UNWTO: http://www2.unwto.org/content/whytourism

\section{BIODATA PENULIS}

Syaiful Ade Septemuryantoro, S.Pi., M.Si., merupakan pengajar pada program studi Pengelolaan Perhotelan Universitas Dian Nuswantoro Semarang.

Penulis mempunyai minat pada pengembangan kajian desa wisata, industri MICE (Meeting, Incentive, Convention and Exhibition)

Id Scholar:

https://scholar.google.com/citations? user $=K$ WEJyqkAAAAJ\&hl=id\&oi=ao 